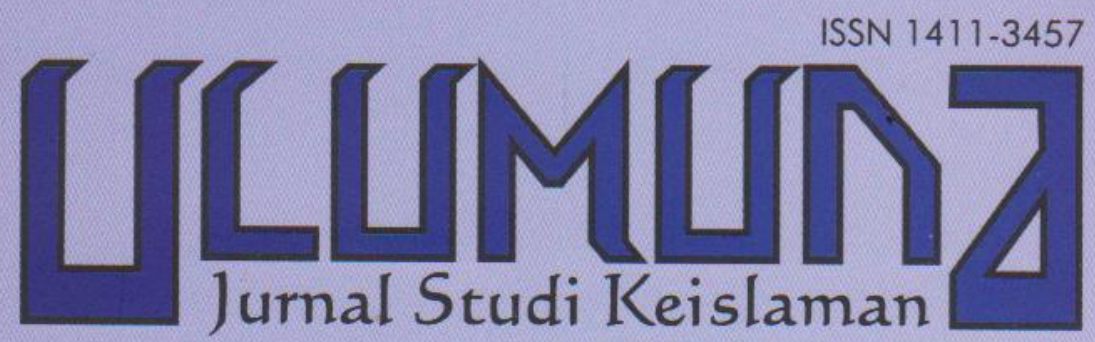

Volume XIII - Nomor 2• Desember 2009

TERAKREDITASI Berdasarkan SK Dirien Dikti Depdiknas Nomor: 65a/DIKTU/Kep/2008

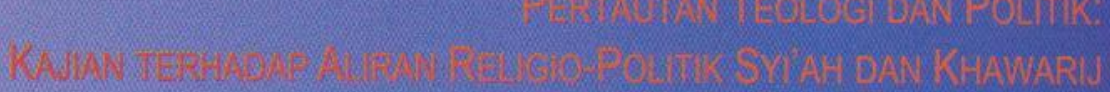

Mustain

TEOLOGI RASIONAL: 2. 6 .02, WLAM MUHAMMAD ABDUH Makrum

TEOLOE LIBERALISME:

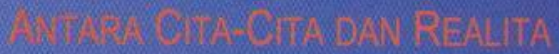
Aswadi

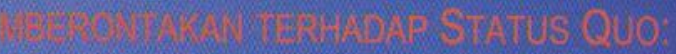

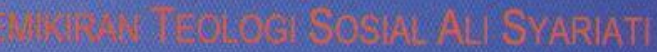
Mukhlis

-1. TONO SAN VISI KEBANGSAAN MASVARAKAT LOMBOK Asnawi

VC. P=R R. PROF-TIK TUAN GURU BSED CAMA OU PULAU LOMBOK Fawaizul Umam 


\section{PEDOMAN TRANSLITERASI}

\begin{tabular}{|c|c|c|c|}
\hline Arab & Latin & Arab & Latin \\
\hline 1 & $=$ & ف & $=\mathbf{f}$ \\
\hline ب & $=$ & ق & $=q$ \\
\hline$\dot{H}$ & $=$ & ك & $=\mathbf{k}$ \\
\hline ج & $=$ & J & $=1$ \\
\hline$\tau$ & $=$ & b & $=\mathrm{m}$ \\
\hline$\dot{\tau}$ & $=\quad \mathrm{kh}$ & $\dot{0}$ & $=\mathbf{n}$ \\
\hline$د$ & $=$ & و & $=\mathbf{w}$ \\
\hline$\dot{j}$ & $d z$ & ○ & $=\mathbf{h}$ \\
\hline J & $=$ & $\&$ & $=$, \\
\hline j & $=$ & ي & $=$ \\
\hline س س & $=$ & & \\
\hline ش ش & sy & \multirow{2}{*}{\multicolumn{2}{|c|}{$\begin{array}{l}\text { Untuk Madd } \\
\text { dan Diftong }\end{array}$}} \\
\hline ص & sh & & \\
\hline ض & dl & i & $=$ â (a panjang) \\
\hline b & th & إي & î (i panjang) \\
\hline ظ & $\mathbf{z h}$ & أو & û (u panjang) \\
\hline$\varepsilon$ & $=$ & آو - - - - & aw \\
\hline$\dot{\varepsilon}$ & gh & آين & ay \\
\hline
\end{tabular}




\section{ISI}

\section{TRANSLITERASI}

\section{ARTIKEL}

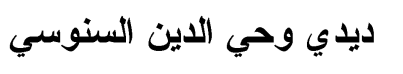

Mustain

Makrum

Halid Al-Kaff

Aswadi

Nurul Anam

Mukhlis

Asnawi

Fawaizul Umam
حفريات علم الكلام ودور المتكلمين 239-268 • في النقافة الإسلامية

Pertautan Teologi dan Politik:

Kajian terhadap Aliran Religio-Politik

Syi'ah dan Khawarij • 269-294

Teologi Rasional:

Telaah atas Pemikiran Kalam

Muhammad Abduh • 295-314

Perspektif Epistemologis

Teologi Islam Liberal • 295-314

Teologi Liberalisme:

Antara Cita-Cita dan Realita • 315-330

Mengurai Benang Kusut

Indikasi Kematian Massal Eksistensi

Tuhan di Abad Globalisasi • 295-314

Islam dan Pemberontakan terhadap

Status Quo: Telaah atas Pemikiran

Teologi Sosial Ali Syariati • 331-356

Paham Teologi dan Visi Kebangsaan

Masyarakat Lombok • 357-382

Tera Ulang Peran Profetik Tuan Guru dalam Konteks Kebebasan Beragama

di Pulau Lombok • 363-416

\section{INDEKS}




\section{ISLAM DAN PEMBERONTAKAN \\ TERHADAP STATUS QUO: TELAAH \\ ATAS PEMIKIRAN TEOLOGI SOSIAL ALI SYARIATI}

Mukhlis*

\section{Abstract}

Ali Syariati, a Syiah moslem intellectual and a doctor in sociology of Islam, has written books and articles that are inspired by his Islamic internalization as a Syiah moslem. This article, through social theological perpective, is aimed at grasping sociological ideas of Syariati's by tracing its theological and philosophical basis and his world view. It is found that his ideas are more an expression of islamic thought which are articulated in sociological terms. His ideas aimed to break the opressor-oppressed relation of Iran people at his time. The spirit of his ideas is to vanish the first and, then, awaken the second so that they are able to quit of the shackle of oppression. Those are responsible to do such a hard duty are rûshanfekr, enlightened intellectual. Qs. 28:5 and Qs. 30:1-4 and 30 are among alQur'an verses that inspired him and became theological arm rest of his ideas.

Keywords: Teologi Sosial, Sosiologi, Status Quo, Determinisme Sejarah, Akstifisme Manusia, Rûshanfeker.

ALI Syariati-seorang doktor dalam sosiologi Islam- termasuk pemikir muslim yang produktif menulis. Tulisannya yang berserakan dalam bentuk artikel-artikel, dengan cirinya yang lugas dan cukup mudah dicerna telah banyak dikaji orang dan diterjemahkan ke dalam berbagai bahasa dari teks-teks asli berbahasa Persia. Meskipun tulisan/pemikirannya mencakup beraneka permasalahan, yang membutuhkan kajian yang multidimensional, kenyataan menunjukkan bahwa kajian tentang

*Penulis adalah dosen pada Fakultas Syariah IAIN Mataram. email: mukhlisabali@yahoo.co.id 
pemikirannya sebagian besar, atau bahkan hampir semuanya, berada dalam bingkai sosiologi dan politik. Maksud kajian-kajian itu tentu bukan untuk mereduksi atau menghasilkan ulasan yang picik dan simplistis tentang Syariati, tetapi lebih karena tuntutan fokus. Setiap kajian, demi ketajaman analisisnya, membutuhkan fokus substansi dan tinjauan.

Tulisan ini hendak memotret pemikiran Syariati dalam fokus sosiologi, khususnya akar teologis dan filosofis yang melatari gagasan-gagasan sosiologisnya. Dalam konteks pengertian itulah istilah teologi sosial digunakan dalam tulisan ini. Pengertian istilah teologi sosial (social theology) itu sendiri secara sederhana sebenarnya dapat dirujuk kepada arti dari dua kata yang membentuknya, yaitu teologi dan sosial. Kata teologi berarti "the study of the nature of God and religious truth; rational inquiry into religious questions" (kajian tentang hakekat Tuhan dan kebenaran agama; menemukan jawaban yang rasional terhadap pertanyaanpertanyaan agama); sosial berarti "of, relating to, or occupied with matters affecting human welfare" (tentang, berhubungan dengan, atau terkait dengan hal-hal yang mempengaruhi kesejahteraan manusia). ${ }^{1}$ Berdasarkan itu John H. Boer mendefinisikan teologi sosial sebagai "the systematic study of and preoccupation with issues of buman welfare from the perspective of divine revelation" (kajian yang sistematik tentang dan pergumulan dengan isu-isu kesejahteraan manusia dari perspektif wahyu Tuhan). ${ }^{2}$ Menurut Duncan Forrester dan Alistair Kee, perhatian utama kajian teologi sosial adalah hubungan antara teologi dan ilmu-ilmu sosial, dan relevansi sosial teologi). ${ }^{3}$

Dengan pengertian tersebut di atas maka dalam mengelaborasi gagasan-gagasan sosiologi Syariati penulis berasumsi bahwa gagasan-gagasannya itu berkaitan dengan pandangan teologis dan, lebih jauh lagi, pandangan dunia (world view) dan filsafat tertentu yang dianutnya; yang mencakup

${ }^{1}$ The American Heritage Dictionary of the English Language, Fourth Edition.

2"Social Theology", http://www.socialtheology.com, diakses tanggal 30 November 2009.

3Duncan Forrester dan Alistair Kee, "General Editors' Preface" dalam Religion and the Making of Society: Essays in Social Theology, ed. Charles Davis (New York \& Melbourne: Cambridge University Press, 1994), xii. 
pandangan ontologik, epistemologik dan filsafat sejarah. Sebelum masuk kepada uraian tersebut maka dipandang perlu untuk mengenal Syariati dari kilasan biografinya di bawah ini.

\section{Sekilas Biografi Syariati}

Penelusuran biografi dibutuhkan untuk membangun perspektif historis tentang figur yang sedang dikaji. Paparan tentang biografi Syariati dalam tulisan ini merupakan ringkasan dari beberapa sumber yang saling melengkapi, seperti dari tulisan Ervand Abrahamian, ${ }^{4}$ Shahrough Akhavi, ${ }^{5}$ Abulaziz Sachedina, ${ }^{6}$ dan terutama sekali dari studi yang dilakukan oleh Ali Rahmena. ${ }^{7}$

Perjalanan hidup Syariati menggambarkan perjalanan hidup seorang tokoh yang penuh tantangan, gejolak, dan kemudian berakhir dengan tragis. Syariati dilahirkan pada tanggal 24 Nopember 1933 di salah satu dusun di Iran. Berkedudukan sebagai putera sulung, kelahirannya tentu disambut dengan penuh suka cita oleh kedua orang tuanya, pasangan Muhammad Taqi dan Zahra. Dia hidup dan berkembang selayaknya bocah lain yang seusia dan hidup sejaman dengannya. Namun beberapa keunikan dalam perilaku-misalnya, tampak suka merenung dan banyak membaca buku-membedakannya dari bocah lain; rupanya semua itu menjadi bagian dari proses pembentukan jati dirinya kelak.

${ }^{4}$ Ervand Abrahamian, Radical Islam: The Iranian Mujahedin (London: I. B. Tauris, 1989), khusus bab yang membahas Syariati, 105-25.

5Shahrough Akhavi, "Ali Syariati", dalam The Oxford Encyclopedia of the Modern Islamic World, vol. IV, ed. in chief John L. Esposito (New York: Oxford University Press, 1995).

${ }^{6}$ Abulaziz Sachedina, "Ali Shariati: Ideologue of the Iranian Revolution", dalam Voices of Resurgent Islam, ed. John L. Esposito (New York: Oxford University Press, 1983).

${ }^{7}$ Ali Rahnema, An Islamic Utopian, A Political Biography of 'Ali Shari'ati (London and New York: I. B. Tauris, 1998), dan "Ali Shariati: Teacher, Preacher, Rebel”, dalam Pioneers of Islamic Revival, ed. Ali Rahnema (New York: Zed Books, 2005), 208-250, atau dalam versi bahasa Indonesia "Ali Syariati: Guru, Penceramah dan Pemberontak", dalam Para Perintis Zaman Baru Islam, ed. Ali Rahmena, ter. Ilyas Hasan (Bandung: Mizan, 1996), 20344. 
Pada usia 7 tahun (1941), Syariati memasuki pendidikan dasar. Di sekolah dia berperilaku pendiam, tidak mau terlalu diatur-atur, dan rajin. Dia tidak suka bermain-main seperti anakanak seusianya dan lebih suka menerawang. Ternyata ini merupakan bawaan kepribadiannya. Ketika dia mulai masuk sekolah menengah atas, dia mulai menyenangi filsafat dan mistisisme. Untuk itu dia betah berlama-lama di perpustakaan ayahnya yang koleksinya mencapai 2000 buku. Jenjang pendidikan menengah ditempuhnya dalam rentang tahun 19461950, dan selama dua tahun berikutnya dia menyelesaikan Kolese Pendidikan Guru di Masyhad.

Untuk pertama kali, mungkin karena kecenderungannya yang suka merenung dan menggeluti berbagai buku, pada rentang usianya yang masih belia, 13-17 tahun, yaitu antara tahun 19461950, dia mengalami krisis kepribadian. Keasyikannya membaca dan berpikir membuatnya mengalami krisis keimanan yang serius. Dia merasa berada di jalan buntu filosofis, yang akibatnya, menurutnya, hanya bisa diatasi dengan bunuh diri atau gila. Pada suatu malam musim dingin dia berpikir untuk bunuh diri di Estakhr-e Koohnsangi yang romantis di Masyhad. ${ }^{8}$ Untunglah pandangan mistisisme Maulawi ${ }^{9}$ dalam Masnawi ${ }^{10}$ yang telah dibacanya menyelamatkannya dari kehancuran diri itu.

${ }^{8}$ Masyhad adalah kota penting — terletak di bagian tenggara wilayah Iran, dekat dengan kota Tûs_-di mana terdapat makam Khalifah Hârûn al-Rasyîd dan Imam Syiah ke-8, Alî Ridlâ. Kata "masyhad” (Arab) berarti "tempat gugurnya pahlawan atau orang suci" dan bisa juga berarti "suatu iringiringan pemakaman”. Bagi kaum Syiah Imamiyah, kata masyhad itu merujuk kepada makam para imam yang gugur sebagai syuhadâ', martyrs. Gordon D. Newby, "Mashhad", dalam A Concise Encyclopedia of Islam (Oxford-England: Oneworld Publications, 2004), 142

${ }^{9}$ Maulawi adalah sebutan singkat untuk tokoh mistik Islam, Maulana Jalaluddin Rumi; kata itu juga menjadi nama singkat untuk tarekat yang dibentuk oleh Rumi, tarekat Sufi Mawlawi. Rumi dilahirkan di Wakhsh (Tajikistan) pada tanggal 30 September 1207 dari sebuah keluarga yang mendalami teologi. Untuk menghindari invasi dan penghancuran oleh Mongol, Rumi dan keluarganya mengelana ke negeri-negeri muslim, melaksanakan haji ke Mekkah, dan akhirnya tinggal di Konya, Anatolia, bagian dari Kerajaan Seljuk. Ketika bapaknya, Bahaduddin Valad wafat, Rumi menggantikannya pada tahun 1231 sebagai professor dalam ilmu-ilmu agama; pada usia 24 tahun Rumi telah menjadi sarjana dalam ilmu agama 
Terlepas dari krisis kepribadian, setelah tamat dari Kolese Pendidikan Guru, Syariati menemukan kedamaian dan keseimbangan baru. Dia menemukan Islam sebagai medium epistemologi untuk menemukan dan mendefinisikan kehidupan dan masyarakat ideal. Model peran atau agen untuk mencapai masyarakat ideal itu, menurutnya, ada pada watak Abu Dzar alGhifari. Melalui figur Abu Dzar, dia menciptakan pahlawan, model dan simbol yang tegar menghadapi kekayaan, kekuasaan dan bahkan otoritas keagamaan, untuk menyelamatkan Islam "otentik" kaum miskin, tertindas dan kaum yang sadar sosial. Dari sinilah kemudian lahir dua karya penting yang ditulisnya antara tahun 1953-1956, yaitu Tarikh-e Takamol-e Falsafe (Sejarah Perkembangan Filsafat), dan Abu Dzar-e Gbifari.

Pemunculan figur Abu Dzar dalam kerangka pemikiran Syariati bermula ketika dia belajar bahasa Arab dengan bapaknya dan menerjemahkan secara agak bebas sebuah karya

dan positive sciences. Perkenalannya dengan dunia mistik adalah melalui tokoh darwis (zâhid) Syamsuddin al-Tabriz. Karya monumental Rumi adalah sebuah enam-volume epik yang berjudul Matsnawi yang oleh pengagumnya terkadang disebut dengan "al-Qur'an dalam Bahasa Persia". General idea dalam puisi-puisi Rumi adalah kecintaan mutlak kepada Tuhan. Pengaruhnya terhadap pemikiran, sastra dan berbagai bentuk ekspresi estetis dalam dunia Islam tidak terbantahkan. Rumi wafat pada tanggal 17 Desember 1273. Hingga sekarang, para pengikut Maulawi tetap melaksanakan peringatan dan perayaan pada tanggal kematiannya itu. Karya-karya Rumi yang ditulisnya dalam bahasa Persia telah diterjemahkan kedalam berbagai bahasa di dunia. Terjemahan dalam bahasa Inggris yang terkenal adalah Annemarie Schimmel, Look! This is Love: Poems of Rumi (Boston: Shambhala Publications, 1991) dan Fatemeh Keshavarz, Reading Mystical Lyric: The Case of Jalal al-Din Rumi (University of South Carolina Press, 1998).

${ }_{10}$ Masnawi adalah magnum opus Jalaluddin Rumi yang menempatkannya sebagai seorang sufi besar sepanjang jaman. Karya itu ditulis dalam bahasa Persia dan telah diterjemahkan dalam banyak bahasa di dunia. Salah satunya adalah terjemahan dalam bahasa Inggris oleh E. H. Whinfield. Masnawi terdiri dari 6 buku/bab yang masing-masing berisi 78 kisah spiritual yang sarat nilai dan ajaran sufistik. Menurut versi terjemahan Whinfield itu, buku 1 (h. 1-90) memuat 16 kisah, buku 2 (h. 91-164) 18 kisah, buku 3 (h. 165252) 18 cerita kisah, buku 4 (h. 253-324) 9 kisah, buku 5 (h. 325-402) 8 kisah, dan buku 6 (h. 403-483) 9 kisah. Lihat Maulana Jalaluddin Rumi, Masnavi I Ma'navi_Teachings of Rumi The Spiritual Couplets, ter. E. H. Whinfield (Ames, Iowa: Omphaloskepsis, 2001). 
berbahasa Arab seorang novelis Mesir, Abdul Hamid Jawwad. Buku yang diberinya judul Abu Zarr: Khodaparast-e Sosiyalist (Abu Dzar: Sosialis Penyembah-Tuhan) dan diterbitkan di Masyhad pada tahun 1956 itu mengklaim bahwa Abu Dzar adalah sosialis pertama di dunia. ${ }^{11}$

Dalam pada itu, masa antara 1953 dan 1956 merupakan masa yang sangat penting dalam perkembangan pemikiran Syariati selanjutnya. Pemerintahan nasionalis demokratis pimpinan Mosaddeq, yang sangat didukung oleh Syariati dan merebut kekuasaan pada tahun 1951, digulingkan pada bulan Agustus 1953. Semenjak itu, aspirasi anti-imperialisme dan nasionalis kaum muda yang ikut dalam gerakan rakyat dibungkam; segala upaya perlawanan secara sistematis dapat diatasi penguasa baru. Harapan untuk kemerdekaan dan kemakmuran Iran yang dilekatkan pada gerakan rakyat berubah menjadi frustrasi dan keputusasaan. Refleksi mendalam terhadap suasana hati nasional itu menciptakan krisis kepribadian kedua pada Syariati, yang saat itu berusia 22 tahun. ${ }^{12}$

Pendidikan formal Syariati tidak terhalang oleh kondisi tersebut. Tahun 1955, dia kuliah di Fakultas Sastera Universitas Masyhad. Akhir tahun 1958, lima bulan setelah menikah dengan Pouran pada tanggal 15 Juli, dia meraih gelar B.A., dan karena prestasinya baik, dia mendapat beasiswa melanjutkan studi ke luar negeri, ke Paris. Pada bulan April 1959 dia berangkat ke Paris yang setahun kemudian disusul oleh isteri dan anaknya.

Masa belajar di Paris adalah episiode yang krusial dalam perkembangan pemikiran Syariati. Baginya, Paris adalah tempat yang mengerikan, namun mendidik dan sekaligus mempesona; dia membenci aspek tertentu dan memuji aspek lainnya. Di satu sisi dia memandang hina kebobrokan sosial dan degradasi moral Paris yang tercermin pada wanita-wanita jalanan, rumah-rumah

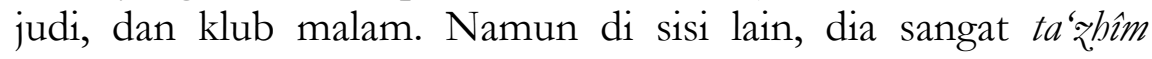
(kagum) pada kesadaran sosial dan pencerahan intelektual Paris yang tercermin pada orang-orang ternama yang rendah hati dari berbagai lembaga pendidikannya.

${ }^{11}$ Abrahamian, Radical..., 106.

12Rahmena, “Ali...", 211. 
Selama di Paris dia mengikuti kuliah-kuliah Louis Massignon dan Henri Corbin, dua orientalis dan ahli tentang mistisisme Islam. Dia menerjemahkan buku Massignon tentang al-Hallaj dan Salman Pak, dua ahli mistik Abad Pertengahan yang dihukum mati karena menentang ortodoksi pada masanya. Syariati mengakui bahwa Massignon adalah tokoh paling penting yang mempengaruhi dirinya. ${ }^{13}$

Syariati juga mengikuti kuliah-kuliah yang diberikan oleh Raymond Aron, Roger Graudy (intelektual komunis Prancis yang menginginkan dialog antara Marxisme dan Kristen), George Politzer (filosof komunis ortodoks), dan terutama Georges Gurvitch. Gurvitch adalah tokoh terkemuka dalam sosiologi di Prancis saat itu dan pendiri mazhab sosiologi dialektis. Selama lima tahun dia mengikuti kuliah-kuliahnya di Universitas Sorborne. Di kemudian hari, dia mengakui, bahwa setelah Massignon, Gurvitch-lah orang yang paling berpengaruh pada dirinya, ${ }^{14}$ bahkan menganggapnya sebagai Abu Dzar versi Barat. Gurvitch yang menghabiskan hidupnya untuk melawan Fasisme, kediktatoran Stalin, dan kolonialisme Perancis di Aljazair, baginya, lebih dekat kepada semangat Syi'ah ketimbang Ayatullah Milani, salah seorang sumber panutan di Iran saat itu, yang tak pernah berjuang sama sekali. ${ }^{15}$

Pada bulan September 1964, Syariati kembali ke Iran. Dia menuju Masyhad dan berharap mendapat pekerjaan di universitas. Inilah permulaan kehidupan yang penuh dedikasi untuk mengartikulasikan, merumuskan dan menyebarkan ideologi Islam radikal yang diharapkan bisa melahirkan gerakan politik Islam radikal di kalangan muda Iran. Ini semua berlangsung selama tiga belas tahun.

Masa tiga belas tahun itu, oleh Ali Rahmena dibagi menjadi lima periode, yaitu: (1) Nopember 1964 sampai Desember 1967, merupakan periode kekecewaan dan kehilangan harapan; (2) Antara 1967 sampai 1971, periode masuknya Syariati ke arena

${ }^{13}$ Ali Syariati, Kavir (Kavir Desert: 1970), 9-10, dikutip dari Abrahamian, Radical..., 107.

${ }^{14}$ Ibid., 108.

15Rahmena, “Ali Syariati ...”, 217. 
universitas, kontaknya dengan mahasiswa, popularitas ide-ide dan keterkenalannya; (3) Bulan Oktober 1971 sampai 19 Nopember 1972, saat ditutupnya Husainiyah Ersyad, tempat dia mengajar, menancapkan akar dan melebarkan sayap pengaruhnya. Pada periode ini terjadi perubahan dalam wacananya, dari membangkitkan kesadaran menjadi ajakan melakukan aksi dan pemberontakan politik. Oleh karena itu, periode ini dapat disebut sebagai periode pemberontakan; (4) Antara Nopember 1972 dan Maret 1975, merupakan periode dibungkam dan dipenjara. Setelah kehilangan mimbar dan audien di Husainiyah Ersyad, dia merasa tercerabut dari akarnya dan dipaksa bungkam serta menjauh dari arena sosial politik. Pada bulan September 1973 dia diinterogasi pasukan penguasa dan akhirnya dijebloskan dalam penjara selama delapan belas bulan. Dia dibebaskan pada bulan Maret 1975; (5) Antara Maret 1975 dan Mei 1977, saat ketika dia meninggalkan Iran, merupakan periode isolasi dan perenungan. Dia merefleksi dan menilai kembali segenap perjuangan dan sepak terjangnya.

Demikianlah perjalanan hidup Ali Syariati yang penuh liku. Dia meninggalkan Iran pada tanggal 16 Mei 1977 dan pada pagi hari tanggal 19 Juni 1977 jasadnya ditemukan terkapar, terbunuh, di lantai rumah yang disewanya di Southhampton, Inggris. Sang tokoh tewas dengan cara yang tragis dan misterius, lebih-lebih bila dikaitkan dengan sepak terjangnya dalam dunia sosial politik.

\section{World View Tauhid: Kesatuan Tuhan-Alam-Manusia}

Pada bagian ini, saya memaparkan pandangan ontologik Syariati yang merupakan salah satu pondasi bagi gagasan-gagasan teologi sosialnya. Pertanyaan pokok yang hendak diurai adalah bagaimana dia memahami dan mengkonstruk tentang kenyataan atau realitas?; apakah pandangan dunia atau world view yang dia anut?.

Menurut Syariati, dasar bagi kenyataan adalah kesatuan antara Tuhan, alam, dan manusia. Kesatuan-tiga yang merupakan refleksi dari pengertian tauhid ini merupakan pusat world view (pandangan dunia) integralisnya (jabambini-ye taubidi). Manusia bertindak sesuai kehendak Tuhan yang mewujud dalam hukum-hukum yang melingkupi alam. Baginya, pandangan dunia 
ini memberikan ruangan yang cukup untuk manusia menjadi individu mandiri yang bertanggung jawab penuh atas segala tindakannya. ${ }^{16}$ Dengan pandangan ini secara implisit dia menganut doktrin kausalitas, sebab-akibat. Dia menolak pandangan dunia Asy'ariah yang okasionalistik, sebaliknya dia tampak lebih cenderung kepada Mu'tazilah yang bersikap rasionalistik.

Bagaimanakah pola hubungan dalam kesatuan-tiga tersebut? Secara sederhana Syariati menjelaskannya sebagai berikut:

"Hubungan antara manusia dengan Tuhan, antara alam dengan meta alam, alam dengan Tuhan adalah sama dengan hubungan antara cahaya dengan lampu yang memancarkannya. Sama dengan hubungan antara kesadaran individu tentang anggota badannya dengan anggota badan itu sendiri: persepsinya tidaklah terpisah dari anggota badan, tetapi bukan bagian dari anggota badan. Anggota badan tanpa kesadaran tidak lebih dari mayat. Tauhid menunjukkan pandangan dunia khas yang mengandung kesatuan universal secara eksistensial. Kesatuan antara ketiganya, karena memiliki asal yang sama. Ketiganya memiliki arah, kehendak, spirit, gerak dan hidup yang sama."17

Pandangan ontologis ini mengindikasikan keharmonisan dan tidak boleh ada pertentangan-pertentangan; Karena, jika di atas segala sesuatu adalah kesatuan-tiga tersebut, maka pertentanganpertentangan menjadi tidak mungkin. Hanya saja kesatuan yang dimaksud adalah kesatuan dalam spirit, arah dan tujuan atau taubîd wujûdi, bukan dalam pengertian substansi atau wahdah alwujûd.

Syariati menginterpretasikan konsep tauhîd tidak sekedar "Tuhan itu tunggal", tetapi lebih daripada itu dia menjadikannya sebagai satu pandangan ontologis dalam memahami manusia, alam dan Tuhan. Struktur utama taubîd menolak kontradiksi dan disharmoni dalam dunia. Oleh karena itu tidak ada kontradiksi dalam segala eksistensi: antara manusia dan alam, jiwa dan badan, dunia dan akhirat, benda dan makna. Lawan dari taubîd

16Shahrough Akhavi, "Shariati's Social Thought", dalam Religion and Politics in Iran, Shi'ism from Quietism to Revolution, editor Nikkie R. Kiddie (New Haven and London: Yale University Press, 1983), 127.

${ }^{17}$ Ali Syariati, On the Sociology of Islam, ter. dan ed. Hamid Algar (Berkley: Mizan Press, 1979), 83. 
adalah syirik, syirk, yaitu pandangan dunia yang menempatkan segala sesuatu dalam kontradiksi dan disharmoni. ${ }^{18}$

Syariati membagi realitas atau "yang ada" (being) menjadi dua, yaitu "yang tersembunyi" dan "yang nyata/tampak". Konsisten dengan pandangan tawhid wujûdî-nya, pembagian itu tidak dimaksudkannya sebagai suatu dualisme ontologis, tetapi hanya klasifikasi relatif manusiawi untuk menyederhanakan penjelasan. Pertama, "yang tersembunyi" berada di luar wilayah pengujian, observasi dan eksperimentasi; sebagai konsekuensinya, ia berada di luar wilayah pengetahuan manusia. Kedua, "yang nyata" berada dalam jangkauan observasi, dapat di tangkap indera dan diuji oleh manusia; sebagai konsekuensinya ia berada dalam wilayah pengetahuan. ${ }^{19}$

Pembagian itu juga sekaligus akan meletakkan dasar bagi keterkaitan antara pandangan ontologinya dengan pandangan epistemologinya, sebagaimana akan diuraikan dalam sub bahasan berikut ini. Lebih dari itu, pandangan ontologi itu membawa implikasi yang jauh terhadap keseluruhan gagasan-gagasan sosiologisnya. Uraian tentang hal itu akan dikemukakan secara lebih detail pada bagian tersendiri dalam tulisan ini setelah uraian tentang pandangan epistemologi dan filsafat sejarah Syariati.

\section{Manusia Mengetahui Sendiri}

Teori pengetahuan dalam Islam klasik bersandar pada konsep kasb, yaitu bahwa pengetahuan manusia tergantung pada Tuhan. Meskipun manusia menunjukkan usaha-usaha untuk memperoleh pengetahuan, tetapi keputusan akhir tentang keberhasilannya dalam menguasai pengetahuan itu sepenuhnya merupakan ketentuan Tuhan. Jadi, tidak ada independensi atau otonomi kekuasaan manusia dalam keberhasilan menggapai penguasaan ilmu. Berbeda dari padangan epistemologis tersebut, Syariati berpandangan bahwa manusia mampu memperoleh sendiri pengetahuan melalui interaksi sosial dalam dunia nyata dan berkoordinasi dengan hubungan interaktif antara Tuhan, alam, dan manusia. Kemampuan manusia untuk memperoleh

${ }^{18}$ Ibid., 86.

${ }^{19}$ Ibid., 83. 
dan menguasai pengetahun dimungkinkan karena manusia memiliki tiga ciri utama, yaitu: memiliki kesadaran, memiliki kebebasan memilih, dan memiliki daya kreatifitas. Optimalisasi tiga ciri utama itu akan melahirkan manusia tiga dimensional yang berkualitas. ${ }^{20}$

Pandangan epistemologi itu sejalan dengan pandangan ontologinya yang membagi "yang ada" (being) menjadi dua, yaitu "yang tersembunyi" dan "yang nyata/tampak". "Yang tersembunyi" berada di luar wilayah pengetahuan manusia, sedangkan "yang nyata" itu masuk dalam wilayah pengetahuan. Tetapi, penting untuk ditegaskan bahwa pembagian itu bukanlah dualisme ontologis, melainkan klasifikasi relatif manusia dan sarana kognitifnya atau sekedar pembagian epistemologi dan logika yang dalam sains pun diterapkan. ${ }^{21}$

Realitas yang utama adalah "yang tersembunyi", yang disebutnya dengan $d z a \hat{t}$, yang tetap tak tersentuh dan dipahami seutuhnya oleh manusia. Kebalikan dari itu "yang nyata", disebutnya dengan âyat, adalah hal-hal yang konkrit, keseharian dan objek-objek material dalam hidup. Manusia secara otonom menggunakan âyât untuk memahami $d z a ̂ t .{ }^{22}$ Âyat-bisa disebut sebagai fenomena-hanya memiliki pengertian identifikasi atau manifestasi dari sesuatu di baliknya, dzât. Dengan pandangan epistemologis tersebut Syariati menginginkan manusia menjadi individu otonom dalam tindakan dan pilihan-pilihan sosialnya. Dia bisa bertindak secara independen sesuai dengan apa yang ditangkap dan dipahaminya dari "yang nyata", âât.

Berdasarkan pengetahuan yang mampu dikuasainya tentang sesuatu hal manusia terklasifikasi mulai dari yang paling mumpuni hingga kepada yang awam. Dalam konteks penguasaan atas pengetahuan tentang Islam, Syariati mengidentifikasi adanya tiga kelompok, yaitu sarjana Islam yang memahami Islam, sarjana Islam yang hanya telah belajar Islam, dan sarjana yang memahami Islam dengan baik tetapi mereka

${ }^{20}$ Ali Syari'ati, Tugas Cendekiawan Muslim, ter. Amin Rais Jakarta: Rajawali Press, 1984), 40-1.

${ }^{21}$ Ali Syariati, On the..., 83.

${ }^{22} \mathrm{Ali}$ Syariati, Islamshenasi, 51, dikutip dari Shahrough Akhavi, "Shariati's...", 130-1. 
tidak dinilai sebagai sarjana Islam. Dalam hal ini, dia menghargai kelompok pertama sebagai yang tertinggi karena mereka tidak saja memiliki pengetahuan tentang Islam tetapi juga mampu meresapi dan menangkap spirit dan makna terdalam dari ide-ide Islam itu sendiri; sedangkan kelompok ketiga dipandang lebih baik daripada kelompok kedua. Penilaian yang demikian timbul karena Syariati membedakan antara "mengetahui" (knowing) dan "memahami" (understanding). Istilah kedua secara implisit sudah mencakup istilah pertama, dan bahkan melampauinya karena ia mencakup juga pemahaman akan semangat terdalam dan orientasi mendasar dari Islam. ${ }^{23}$ Para sarjana Islam yang termasuk dalam kelompok pertama itulah yang dirujuk oleh Syariati dengan sebutan rûshanfeker, ${ }^{24}$ kaum cendekiawan.

\section{Dialektika Sejarah}

Karya-karya Syariati mengandung weltanschaung tertentu tentang sejarah. Dia menolak pandangan skeptik terhadap sejarah yang memandang sejarah sebagai sesuatu yang tak berguna dan kebohongan belaka, seperti dalam ungkapan Napoleon, "History is no more than lies which are accepted by all". Sebaliknya, Syariati memandang sejarah dengan spirit yang positif dan meletakkannya sebagai media untuk memahami hukum-hukum kehidupan dan merancang masa depan umat manusia. Sejarah merupakan realitas alamiah yang hidup, bukan suatu proses yang tidak logis tidak bertujuan. Dia menyatakan:

"Sejarah adalah suatu proses yang padu dan berkelanjutan yang bergerak dan tumbuh dari awal mula kehidupan manusia sesuai dengan hukum

23Lihat Ali Syariati, School of Thought and Action, ter. Cyrus Bakhtiar (Albuquerque, NM: Abjad, tt), 22-4. Buku ini-terjemahan dari teks asli dalam bahasa Persia_adalah publikasi dari pelajaran pertama dari total 27 pelajaran dalam kuliah-kuliah islamologi yang diberikan oleh Ali Syariati di Husainiyah Irsyad, Teheran, dari tanggal 4 Februari 1972 hingga 10 November 1972.

${ }^{24}$ Istilah dalam bahasa Persia ini diterjemahkan secara beragam, seperti enlightened thinkers, kaum intelegensia, free thinkers, dan lain-lain. Namun Syariati sendiri menerjemahkannya dengan istilah intelegentsia. Lihat, Akhavi, "Shariati's...", 113. Atas dasar itu penulis menggunakan istilah "kaum cendekiawan" sebagai pengindonesiaan istilah rûshanfekr. 
sebab akibat yang bersifat saintifik dan deterministik. Ia berlalu dengan penuh pasti melewati tahap-tahap yang berbeda-beda dan menemui titik-titik tertentu yang dapat diperkirakan sebelumnya. Akhirnya, ia pasti mencapai tujuan-tujuannya yang telah ditentukan sebelumnya, predetermined, oleh hukum pergerakan sejarah, the law of the movement of bistory". ${ }^{25}$

Sejalan dengan pandangan epistemologinya bahwa manusia berkemampuan untuk menggapai dan menguasai pengetahuan, maka Syariati berpendapat bahwa hukum pergerakan sejarah itu adalah sesuatu yang dapat dan niscaya untuk diketahui oleh manusia. Pengetahuan itu memberikan manfaat besar bagi manusia. Dalam hal ini dia menyatakan:

“Oleh karena itu, jika kita menemukan alur pergerakan sejarah, maka
kita dapat menduga apa yang akan terjadi di masa depan. Seseorang yang
meyakini prinsip ini, yang percaya pada filosofi sejarah ... percaya bahwa
sejarah adalah suatu realitas yang saintifik dan suatu pergerakan yang
mengalir mengikuti hukum-hukum saintifik yang pasti. Oleh karena itu,
nasib kemanusiaan sepanjang jaman bukan sesuatu yang kebetulan. Ia
bukan diciptakan oleh orang-orang, juga tidak menetap atau bergerak,
mundur atau maju menurut kehendak si ini atau si itu. Ia bergerak
menurut hukum-hukum saintifik yang memaksa, yang ada dalam setiap
susunan masyarakat dan rentetan waktu. Pergerakan itulah yang disebut
sejarah. Oleh karena itu, sejarah adalah suatu alur yang deterministik dan
berkelanjutan yang bergerak sesuai dengan hukum-hukum yang pasti.
Itulah yang disebut dengan percaya pada filosofi sejarah". ${ }^{26}$

Dalam konteks sejarah perkembangan manusia maka kepastian sejarah itu yang disebutnya dengan jabar-e tarikhi (determinisme sejarah), harakat-e dialektiki (pergerakan dialektik), dan dialektek-e tarikhi (dialektika sejarah) itu pun memainkan peranan vital. Motor perkembangan manusia adalah kehendak Tuhan yang termanifestasi dalam hukum pergerakan sejarah yang pasti, hasrat dalam diri manusia untuk mencapai tahap kesadaran yang lebih tinggi, dan perjuangan kelas yang disimbolkan dalam kisah Injili tentang Habil dan Qabil. ${ }^{27}$

${ }^{25}$ Syariati, School..., 37.

26Ibid., 37-8.

27Abrahamian, Radical..., 111. 
Pemunculan kisah Habil dan Qabil adalah bagian penting dalam pemikiran Syariati dalam rangka upayanya menerjemahkan pandangan ontologi, epistemologi, dan filsafat sejarahnya. Persembahan yang dilakukan oleh Habil berupa seekor unta menunjukkan bahwa dia adalah seorang penggembala; dia mewakili tahap sejarah ketika eksistensi manusia tergantung pada alam-berburu, mencari ikan, dan menjinakkan binatang-ketika prinsip monopoli dan pemilikan secara pribadi belum ada. Di pihak lain, persembahan Qabil berupa seonggok gandum menunjukkan bahwa dia adalah seorang petani; dia mewakili periode sejarah dimana alam dipandang sebagai lahan yang disediakan Tuhan untuk dikuasai dan dimiliki. Pada periode ini telah muncul pemilikan pribadi dan monopoli. ${ }^{28}$ Habil dicitrakan oleh Syariati sebagai orang yang tertindas, dikuasai dan jelata (mustadl'afûn), sedangkan Qabil sebagai penindas, penguasa, dan elit. Dalam sejarah kemanusiaan, pencitraan tersebut mewujud dalam terbentuknya dua kelas masyarakat yang bertentangan. Struktur masyarakat tersusun atas dua unsur, yaitu superstructure yang mencakup negara, sistem resmi dan ideologi dominan; dan infrastructure yang mencakup pola produksi, kelas masyarakat tereksploitasi dan ideologi anutannya yang bertentangan dengan ideologi dominan. ${ }^{29}$ Dalam konteks inilah kedua kelas membentuk agama masing-masing, yaitu agama para penguasa yang memuliakan penindasan, kesewenang-wenangan dan status quo; dan agama para tertindas yang mengartikulasikan pengertian yang sejati tentang benar dan salah, baik dan jahat, keadilan dan ketidakadilan. Agama yang pertama disebutnya sebagai multiteisme, dan yang kedua sebagai monoteisme yang diperjuangkan para nabi. ${ }^{30}$

${ }^{28}$ Ali Syari'ati, Tugas..., 40-1.

${ }^{29}$ Ali Syariati, Darsha-ye Islamshenasi, lesson III, 49-75, dikutip dari Abrahamian, Radical..., 111.

${ }^{30}$ Multiteisme dapat mewujud dalam bentuk penyembahan yang nyata pada berhala-berhala atau paganisme, tetapi bisa juga dalam bentuk yang berkedokkan monoteisme. Bentuk yang kedua inilah yang sangat berbahaya dan paling sulit dikalahkan, tidak seperti yang pertama yang bentuknya jelas dan telah dikalahkan dan dihancurkan oleh misi para nabi Allah. Ia 
Dengan beraksentuasi pada pertentangan abadi itu, Syariati tampaknya menganut filsafat sejarah yang dipengaruhi oleh Marx yang memandang sejarah berlangsung melalui kontradiksikontradiksi dialektis. Sejarah bangkit dalam konteks perseteruan antara kekuatan-kekuatan yang saling bertentangan, semenjak manusia pertama di bumi dan akan terus terjadi di mana saja. ${ }^{31}$

Kesamaan pandangan dengan Marx itu ternyata terjadi pada tataran permukaan saja. Pada tingkat yang lebih substansial dia berbeda dari Marx dalam hal memberikan landasan bagi perseteruan abadi itu. Menurutnya, landasan perseteruan itu bukanlah semata-mata interes ekonomi seperti yang dikemukakan Marx, tetapi lebih oleh faktor-faktor seperti keyakinan agama, simbol-simbol, keadilan dan ketidak-adilan, baik dan jahat, benar dan salah. ${ }^{32}$ Dia juga berbeda dari Marx tentang hubungan antara kekuasaan dan kepemilikan. Baginya, kepemilikan ditentukan oleh kekuasaan, sedangkan Marx berpendapat sebaliknya. Pemilikan terbagi dua, yaitu pemilikan tunggal (monopoli) dan pemilikan umum (sosial). Pada awalnya masyarakat menganut pemilikan bersama di mana sumber daya, peralatan dan barang konsumsi masih tersedia bagi dan menjadi milik setiap orang. Selanjutnya model pemilikan itu bergeser menjadi monopoli di mana barang-barang tersebut dikuasai oleh sebagian kecil orang. Masyarakat menjadi terpolarisasi; ada sebagian kecil anggota yang menguasai sebagian besar sumber daya, dan sebaliknya ada sebagian besar anggota yang menguasai sedikit atau bahkan tidak menguasai apa-apa. ${ }^{33}$

membangun masjid-masjid, membacakan doa-doa, membaca al-Qur'an, dan mengumandangkan slogan-slogan nabi. Namun demikian, semua itu hanya tampilan lahiriahnya saja yang monoteisme, sedangkan batiniahnya adalah multiteisme. Uraian agak rinci tentang hal itu lihat dalam Ali Syari'ati, Agama versus "Agama", ter. Afif Muhammad dan Abdul Syukur (Jakarta: Pustaka Hidayah, 1994), 51-80; kutipan di atas ada pada halaman 68-9.

${ }^{31} \mathrm{Ali}$ Syariati, Islamshenasi, 69-70, dikutip dari Shahrough Akhavi, "Shariati's...", 131.

${ }^{32}$ Abrahamian, Radical..., 108.

${ }^{33}$ Ali Syariati, "Mesin dan Belenggu Mesinisme", dalam Peran Cendekiawan Muslim Mencari Masa Depan Kemanusiaan, Sebuab Wawasan Sosiologis, ter. Team Naskah Salahuddin Press (Yogyakarta: Salahuddin Press, 1985), 12. 
Berawal dari polarisasi itu, yang semakin lama semakin tajam, maka berlangsunglah pertentangan abadi antara keduanya, antara kelompok penindas dan tertindas. Sehubungan dengan ini, untuk membangkitkan semangat kaum tertindas, Syariati merumuskan pesan abadi yang terkandung dalam peristiwa terbunuhnya Imam Husain di Karbala, yaitu bahwa sepanjang jaman dan di mana saja setiap orang memikul kewajiban untuk menolak penindasan. Dia sering kali menyatakan: "Setiap bulan adalah Muharram, setiap hari adalah 'Asyura, dan setiap tempat adalah Karbala". 34

Bagaimana pergeseran model kepemilikan itu terjadi, sehingga melahirkan penindasan-penindasan? Syariati mengurainya ke dalam enam tahap perubahan. ${ }^{35}$ Namun keenam tahap itu pada intinya mengemukakan satu hal, bahwa dasar bagi pergeseran pemilikan itu adalah modal yang dimiliki sebagian kecil orang yang dengannya mereka bisa membeli sumber daya alam dan sarana produksi.

Perbedaan lain antara Syariati dan Marx atau kaum materialis adalah berkaitan dengan free will manusia dan determinisme

${ }^{34}$ Abrahamian, Radical..., 112.

35Dengan mengamati rantai perubahan sosial hingga abad XIX, Syariati mengisyaratkan adanya enam tahap perubahan sosial yang membawa kepada peralihan kepemilikan tersebut, yaitu: (1) Manusia hidup dalam kelompokkelompok tanpa tatanan sosial timpang dimana setiap pribadi merdeka dan sama derajat. Belum tercipta sarana produksi yang rumit sehingga penduduk belum terbagi-bagi atas dasar pemilikan keahlian. Kalaupun ada, sarana tersebut diatur menjadi milik bersama; (2) Dasar-dasar perbudakan mulai terbentuk, usaha tani berkembang, sementara itu sumber daya mulai terbatas. Secara mendasar, manusia mulai terbagi, dan prinsip-prinsip perbudakan mulai merembes menggeser struktur dasar; (3) Perbudakan berkembang, berubah ke arah prinsip-prinsip kuli kontrak. Meskipun mereka merdeka, keterkaitannya pada lahan membuatnya tak berdaya mengikuti kehendak tuan-tuan tanah, kepada siapa mereka mengabdikan diri; (4) Tumbuhnya benih-benih feodalisme, tata penguasaan di tangan minoritas bangsawan. Hidup para buruh sangat terikat kepada para aristokrat; (5) Struktur dasar terus bergeser ke arah prinsip borjuis. Lapisan ini bukan petani, bukan aristokrat pula, melainkan kelas menengah. Dengan memiliki alat dan sarana-sarana produksi, kelompok ini segera mampu menguasai industri dan mesin; (6) Kaum borjuis telah menguasai mesin, industri dan produksi kian melimpah. Lihat Syariati, "Mesin...", 10-1. 
sejarah. Syariati menilai pandangan kaum materialis membuat manusia tidak bebas, karena semata-mata ditentukan oleh materi. Manusia hanya dilihat sebagai "hewan ekonomi" yang akhirnya menghamba kepada dan diperbudak oleh materi. Sebaliknya, dia berpandangan bahwa manusia adalah makhluk bebas yang kebebasannya hanya dibatasi oleh kematian dan kebutuhan-kebutuhan biologis yang berkaitan dengan makanan, tempat tinggal dan kesehatan. Di luar itu manusia sepenuhnya bebas, dan sebagai konsekuensinya dia sepenuhnya bertanggung jawab atas semua itu. Kebebasan manusia dalam determinisme sejarah digambarkan oleh Syariati ibarat kebebasan ikan di dalam sungai. "Ikan itu bebas berenang kemana saja bahkan melawan arus sekalipun, tetapi dia tidak bisa keluar dari sungai itu."36

\section{Gagasan yang Memberontak Status Quo}

Mungkin karena dipengaruhi oleh kondisi objektif perpolitikan yang otoriter dan represif dalam negeri Iran, maka Syariati banyak menuangkan gagasan sosiologis yang berhubungan dengan politik dan perubahan sosial. Sebagaimana telah dipaparkan di muka bahwa dia sendiri menjadi korban perpolitikan saat itu karena keberaniannya menentang apa yang disebutnya dengan superstructure penindas. Sebagai akibatnya dia harus keluar masuk penjara dan akhirnya tewas dalam pelarian.

Pandangan-pandangan ontologis, epistemologis dan filsafat sejarah Syariati pada prinsipnya bermuara pada keyakinan tentang aktifisme dan "otonomi" manusia. Manusia bersifat mandiri dalam mengatur dan merubah tatanan kehidupannya berdasarkan segenap kemampuan yang dimiliki dan pengetahuan yang diperoleh lewat pemahaman terhadap âyât (tanda, "yang nyata"). Pandangan ini tidak lantas berarti bahwa tidak ada faktor eksternal di luar diri manusia yang menentukan. Justru Syariati menunjuk realitas yang utama adalah "yang gaib" (the bidden, dzât), tetapi unknownable, tak dapat diketahui seutuhnya. Maka tidak ada seorang manusia pun kini yang bisa mengklaim memiliki pengetahuan yang seutuhnya tentang "yang gaib" dan

${ }^{36}$ Ali Syariati, Jabr-e Tarikh, 47-9, dikutip dari Shahrough Akhavi, "Shariati's...", 134. 
kemudian memosisikan dirinya sebagai yang paling otoritatif. Tampaknya pandangan ini diarahkan untuk mengecam para ulama, mulla dan ayatullab yang berperilaku dan diperlakukan "lebih dari manusia", meskipun kenyataannya mereka secara sengaja atau tidak mendukung rejim yang menindas manusia Iran. Syariati memang bersikap antiklerikalisme, yaitu menetang kekuasaan ulama yang terpadu dalam dan berkolaborasi dengan struktur kekuasaan yang rigid, seperti yang ditemukan dalam kepemimpinan keagamaan Syiah. Dia menentang keras para pemuka agama yang menyalahgunakan kekuasaan kerohaniahannya untuk kepentingan sendiri dengan memperalat orang lain. ${ }^{37}$

Manusia secara otonom menggunakan "yang nyata" (âyât) untuk memahami "yang gaib" ( $d z \hat{a} t) .{ }^{38}$ Oleh karena itulah maka Syariati memahami ajaran Islam atau "Islam" itu sendiri dari perspektif dan dalam jargon "yang nyata", sosiologis, seperti yang dikemukakannya, Islam yang benar adalah:

"Islamnya Abu Dzar, bukan para khalifah; Islamnya keadilan dan kepemimpinan yang benar, bukan penguasa, aristokrat dan kelas atas; Islamnya kebebasan, kemajuan dan kesadaran, bukan perbudakan, pembungkaman dan kepasifan; Islamnya para mujahid, bukan para ulama; Islamnya kebajikan, pertanggungjawaban pribadi dan protes, bukan kepura-puraan, perantaraan ulama, dan intervensi Tuhan; Islamnya perjuangan demi iman, masyarakat dan pengetahuan ilmiah, bukan penyerahan diri membabi buta, dogmatisme, dan taqlid pada ulama". 39

Tentu saja rumusan itu debatable, karena setiap orang bisa berbeda dalam melihat figur Abu Dzar, konsep keadilan, kepemimpinan yang benar, kebebasan, mujahid, kebajikan, protes, perjuangan, dan lain-lain.

${ }^{37}$ Azumardi Azra, "Ali Syari'ati: Sejarah Masa Depan Umat Islam dan Akar-Akar Ideologi Revolusi Iran", dalam Historiografi Islam Kontemporer: Wacana, Aktualitas, dan Aktor Sejarah (Jakarta: Gramedia Pustaka Utama, 2002), 214.

${ }^{38}$ Syariati, Islamshenasi, 51, dikutip dari Shahrough Akhavi, "Shariati's...", 130-1.

${ }^{39}$ Ali Syariati, Darsha-ye Islamshenasi, lesson II, 98-9, dikutip dari Abrahamian, Radical Islam..., 112. 
Sebagai implikasi pandangan epistemologinya, bahwa manusia sendiri yang aktif dalam memperoleh pengetahuan, maka secara alamiah manusia akan bertingkat-tingkat sesuai dengan perolehannya. Di sinilah Syariati mengidentifikasi sekelompok manusia yang disebutnya dengan rûshanfekr, ${ }^{40}$ kaum cendekiawan. Rûshanfekr adalah "orang-orang alim yang merasa terpanggil untuk memperbaiki masyarakat; berusaha memahami aspirasi mereka; merumuskannya dalam bahasa yang dapat dipahami setiap orang; menawarkan strategi dan alternatif pemecahan masalah." 41

Dengan keunggulan yang dimilikinya, kaum cendekiawan ini berkewajiban merekayasa sosial, merangsang tumbuhnya kesadaran kelas pada masyarakat tertindas, menjadi jembatan penghubung dalam kesenjangan antara para intelektual dan rakyat banyak, dan meruntuhkan keulamaan yang terkooptasi kekuasaan. ${ }^{42}$ Kedudukan kaum cendekiawan ini sangat penting dalam gagasan Syariati tentang perubahan sosial, yang berfungsi sebagai elit dan agen perubahan itu sendiri. Mereka harus mengikuti jejak Hussain yang bersama kaum tertindas menentang penindas. Bagi Syariati, tindakan Hussain itu bukan model bagi masyarakat Syi'ah saja, tetapi juga bagi semua masyarakat dan budaya. ${ }^{43}$

Kaum cendekiawan dalam gagasan sosiologi Syariati memang berperan sangat sentral. Mereka adalah “jembatan” penghubung berbagai kesenjangan dan posisi-posisi kontradiktif-dialektis dalam masyarakat. Mereka menjembatani kesenjangan politik penguasa dan rakyat tertindas; kesenjangan ekonomi penguasa modal dan massa miskin; kesenjangan ulama dan massa awan, dan lain-lain. Peran menjembatani ini merupakan langkah pertama dalam strategi besar rekayasa masyarakat Islam. ${ }^{44}$

${ }^{40}$ Komentar tentang istilah rûshanfeker lihat catatan kaki nomor 24 dalam tulisan ini.

${ }^{41}$ Azra, “Ali Syari'ati...", 215.

${ }^{42}$ Ali Syariati, Revesh-e Shenakht-e Islam (Teheran, 1968), 5, dikutip dari Nikki R. Kiddie (ed.), Religion..., 137.

${ }^{43}$ Akhavi, "Syariati's...", 140.

${ }^{44}$ Lihat Ali Syariati, Membangun Masa Depan Islam, Pesan untuk para Intelektual Muslim, penerj. Rahmani Astuti (Bandung: Mizan, 1993), 26-31. 
Singkat kata, mereka menjalankan peran sintesis dalam aneka dialektika yang ada, dan pada saat yang sama, mereka merasa bertanggung jawab untuk membebaskan rakyat dari keterbelakangan dan ketertindasan.

Ketertindasan (إستضعاف) yang harus dibasmi itu, dalam identifikasi Syariati dengan merujuk kepada Qs. 28:5, meliputi ketertindasan politik, ekonomi, dan intelektual. Ketertindasan politik yang mewujud dalam bentuk suatu kelas ditekan oleh kekuasaan kelas lain ditimbulkan oleh tirani politik; ketertindasan ekonomi disebabkan oleh praktek eksploitasi ekonomi yang mewujud dalam rupa suatu kelas dirampok kekayaannya dan dihisap oleh kelas lain; dan ketetindasan intelektual terjadi karena kelompok lain yang memiliki pemikiran dan kecerdasan dipaksa menjadi bodoh. Syariati menekankan bahwa penindasan intelektual adalah yang paling berbahaya, karena dapat menjadi dasar bagi penindasan politik dan ekonomi. 45

Ada tiga oknum yang menjadi penyebab ketertindasan itu, dan oleh karena itu mereka harus dibasmi, yaitu imperialisme Barat, diktator monarki, dan kerjasama ulama yang mendukung keduanya. ${ }^{46}$ Ketiga oknum itu, yang disebut oleh Syariati dengan trinitas-sumber-kesengsaraan-Iran, berkolaborasi menindas rakyat; maka mereka mewakili kelas penindas yang harus dilawan oleh kaum tertindas. Bila kemenangan telah diraih, maka "tatanan politik (dibangun) atas dasar kepemimpinan yang benar, bukan atas dasar figur pemimpinnya karena itu akan bergeser menjadi fasisme". ${ }^{47}$

Di samping mencela tiga oknum itu, pada saat yang sama Syariati juga menyalahkan massa pasif yang telah memungkinkan berlangsungnya kolaborasi trinitas-sumber-kesengsaraan itu selama berabad-abad. Kesadaran massa pasif ini harus dibangkitkan untuk aktif menentang penindas mereka. Sekali lagi, usaha untuk membangkitkan kesadaran massif ini menjadi

${ }^{45}$ Ali Syariati, Islam Agama Protes, ter. Satrio Pinandito (Jakarta: Pustaka Hidayah, 1993), 76.

46Ali Rahmena, “Ali Syariati...”, 211-2.

${ }^{47}$ Ali Syariati, Islamshenasi, 98-9, dikutip dari Shahrough Akhavi, "Syariati's...", 136. 
tugas yang diemban oleh para kaum cendekiawan itu. Merekalah yang paling bisa menerjemahkan apa yang seharusnya dilakukan.

Dengan membuat polarisasi pertentangan penindas dan tertindas itu maka dialektika dalam pemikiran sosiologi Syariati menjadi sangat kental, yang membuatnya sering dituduh terpengaruh oleh Marx. Tentang masalah itu terjadi polemik yang cukup tajam di kalangan beberapa penulis tentang dirinya. Mangol Bayat, misalnya, mengingatkan para pembaca Syariati agar berhati-hati dalam membaca dua tulisan (buku) Syariati yang diterjemahkan dan disunting ke dalam bahasa Inggris masing-masing dengan judul On the Sociology of Islam oleh Hamid Algar, ${ }^{48}$ dan Marxism and Other Western Fallacies: an Islamic Critique oleh R. Campbell. ${ }^{49}$ Menurut Bayat, penyunting kedua buku itu telah melakukan distorsi-distorsi dalam rangka usaha kerasnya membuktikan bahwa Syariati tidak anti ulama dan tidak terpengaruh oleh Marx. Misalnya, kata mulla (ملا) dalam tulisan asli Syariati diselewengkan menjadi mala' (ملأ), menjadi terkaburkan; Bukan lagi "ulama kolaborator kekuasaaan" yang dihujat oleh Syariati, tetapi menjadi "masa/kekuasaan terdahulu". ${ }^{51}$ Abrahamian juga mengemukakan hal yang sama. ${ }^{52}$ Namun di pihak lain, Hamid Algar selaku penyunting kedua buku itu menyebut mereka (Bayat dan Abrahamian) sarjana gadungan yang mendistorsi

${ }^{48}$ Ali Syari'ati, On the Sociology of Islam, ter. Hamid Algar (Berkeley, Calif.: Mizan Press, 1979). Buku ini juga telah diterjemahkan ke dalam bahasa Indonesia dengan judul Tentang Sosiologi Islam diterbitkan oleh Mizan, Bandung.

${ }^{49}$ Ali Syari'ati, Marxism and Other Western Fallacies: An Islamic Critique, ter. R. Campbell (Berkeley, California: Mizan Press, 1980). Buku ini telah diterjemahkan pula ke dalam bahasa Indonesia oleh Husin Anis Al-Habsy dengan judul Kritik Islam atas Marxisme dan Sesat-Pikir Barat Lainnya. (Bandung: Mizan, 1983).

${ }^{50}$ Periksa Ali Syariati, On the Sociology ..., 115.

${ }^{51}$ Lihat Mangol Bayat, "Islam Iran Masa Pahlevi dan Sesudahnya, Tinjauan Revolusi Kultural ?", dalam Islam dan Perubaban Sosial-Politik di Negara Berkembang, ed. John L. Esposito, ter. Wardah Hafidz (Yogyakarta: PLP2M, 1985), 202.

${ }^{52}$ Lihat Abrahamian, Radical...", 110. 
artikel-artikel Syariati untuk membuktikan tuduhan mereka bahwa Syariati terpengaruh oleh ide-ide Sosial-Marxisme. ${ }^{53}$

Menurut saya, dan berdasarkan bacaan yang tersedia, sebenarnya dia bermazhab dialektika Georges Gurvitch yang tidak melihat pertentangan-pertentangan terjadi karena faktor materi dan interes ekonomi seperti yang dikemukakan oleh Marx, tetapi lebih oleh faktor-faktor idealistik, seperti keyakinan agama, simbol-simbol, keadilan dan ketidak-adilan, baik dan jahat, benar dan salah. Bila dirunut lebih jauh, maka dapat disimpulkan bahwa Syariati terpengaruh oleh dialektika idealisme dari Hegel.

Lepas dari kontrovesi tersebut, Syariati sebagai pemikir muslim menjadikan al-Qur'ân sebagai inspirator utama gagasangagasan sosiologisnya, dan atas dasar itulah pemikiran sosiologisnya tidak bisa dipisahkan dari pemikiran teologisnya. Ayat al-Qur'an yang kerap menjadi rujukan Syariati dalam melontarkan gagasan pemberontakan terhadap status quo dan penindasan adalah Qs. al-Rum (30) ayat 1-4 dan 30 yang terjemahannya adalah sebagai berikut:

(1) Alif lâm mîm; (2) Telah dikalahkan bangsa Rumawi; (3) Di negeri yang terdekat dan mereka sesudah dikalahkan itu akan menang; (4) Dalam beberapa tahun lagi bagi Allah-lah urusan sebelum dan sesudah (mereka menang). dan di hari (kemenangan bangsa Rumawi) itu bergembiralah orang-orang yang beriman. (30) Maka hadapkanlah wajahmu dengan lurus kepada agama Allah; (tetaplah atas) fitrah Allah yang telah menciptakan manusia menurut fitrah itu. tidak ada peubahan pada fitrah Allah. (Itulah) agama yang lurus; tetapi kebanyakan manusia tidak mengetahui.

Dari empat ayat pertama dia menyimpulkan bahwa Allah menjanjikan kemenangan bagi setiap kelompok yang berjuang demi hak-haknya melawan penindas. Ini adalah hukum universal, yang dapat diterapkan pada setiap tempat dan waktu, tidak pernah palsu. Semua fenomena di dunia ini akan mengikuti aturan-aturan penciptaan yang tidak akan berubah dan

${ }^{53}$ Lihat Hamid Algar, "Pengantar Editor", dalam Ali Syariati, Kritik Islam atas Marxisme dan Sesat-Pikir Barat Lainnya, ter. Husin Anis Al-Habsy (Bandung: Mizan, 1983), 38. 
tidak bisa diubah oleh siapa pun dan hukum manapun. (ayat 30). ${ }^{54}$ Kedua poin ini, janji dan hukum universal Allah, menurut Syariati, harus selalu dipegang kuat sebagai ideologi abadi.

Ideologi merupakan satu konsep yang juga penting untuk dicermati dalam struktur pemikiran Syariati. Menganut ideologi seperti tersebut di atas, menurutnya, berarti mempunyai keyakinan yang kuat untuk mengubah status quo. Ideologi dapat membantu menjabarkan status quo lengkap dengan keadaan dan tingkatan sosial, historis, geografis dan politik pengikutnya, serta keadaaan mereka dalam perbandingannya dengan kelompok lain yang terlibat dalam masyarakat yang sama. Ideologi dapat menjawab berbagai masalah yang berhubungan dengan kemanusiaan, kelompok-kelompok, kelas sosial dan alam semesta. Begitu pentingnya menganut suatu ideologi itu, sehingga Syariati menjadikannya sebagai kriteria utama apakah seseorang itu dapat disebut rûshanfekr (kaum cendekiawan) atau bukan. ${ }^{55}$

Islam sejatinya, sebagaimana yang diperjuangkan oleh Rasulullah, menurut Syariati, merupakan suatu mazhab ideologi. Dalam pengertian yang demikian itu, Islam adalah suatu sistem keyakinan, bukan suatu budaya; suatu idea bukan sekedar kumpulan pengetahuan; suatu gerakan kemanusian, historis, dan intelektual, bukan tumpukan informasi ilmiah dan teknis; suatu ideologi dalam pikiran kaum cendekiawan, bukan pengetahuan agama yang kolot dalam pikiran para pemuka agama. ${ }^{56}$ Islam dalam pengertian yang demikian itulah yang harus dibangkitkan dan diperjuangkan, dan tugas itu terutama terpikul di pundak para rûshanfekr.

Syariati banyak dikritik karena dalam memahami Islam dia lebih menyukai analisis para islamolog-yang nota bene adalah

${ }^{54}$ Syariati, Membangun..., 122 dan 127.

${ }^{55}$ Ali Syariati, "Ideologi dan Kaum Intelektual", dalam Ideologi Kaum Intelektual, Suatu Wawasan Islam, ed. Syafiq Basri dan dan Haidar Bagir, ter. Farid Gaban (Bandung: Mizan, 1992), 114-5.

${ }^{56} \mathrm{Ali}$ Shariati, School of Thought and Action, ter. Cyrus Bakhtiar (Albuquerque: Abjad), 24. Buku ini adalah pelajaran pertama-total ada 27 pelajaran-dari kuliah-kuliah yang diberikan oleh Syariati dari tanggal 4 Februari 1972 hingga 10 November 1972 di Husayniyah Irsyad di Teheran. 
non-muslim. Bagi Syariati, analisis para islamolog sering mengemukakan citra Islam yang egaliter, humaniter, mistis, dan tegar menentang. Sehungan dengan ini, Syariati berharap agar suatu saat lahir dari rahim komunitas Syi'ah para juru bicara yang mengemukakan Fatimah seperti Sulaiman Katani (dokter Kristen) melukiskan Fatimah; Ali seperti George Jordaq (dokter Kristen) menulis tentang Ali; Ahl al-Bayt seperti yang digambarkan oleh Louis Massignon (orientalis asal Perancis) mengenai mereka dalam penelitiannya; Abu Dzar melalui mata Juddah al-Sahr; al-Qur'an melalui terjemahan seorang pendeta Kristen, Regis Blachere; dan Nabi Muhammad melalui penglihatan Maxime Rodinson, seorang akademisi Yahudi. ${ }^{57}$

\section{Catatan Akhir}

Corak pemikiran seseorang akan sangat ditentukan oleh situasi dan kondisi sosio-politik-historis yang dialaminya, yang disebut juga dengan faktor determinisme sejarah. Jika seseorang berkembang dalam situasi represif dan tersadarkan atas ketertindasannya, maka pastilah wacana yang dikembangkannya adalah wacana pemberontakan terhadap penindasan atas dirinya. Dalam keadaaan demikian tidak ada lagi paradigma yang cocok baginya selain paradigma konflik dan dialektika. Orang yang sesituasi dengannya juga akan menganut paradigma yang sama meskipun mereka bisa saling berbeda dalam menentukan landasan bagi konflik dan dialektikanya, materialisme (Marxian) atau idealisme (Hegelian).

Syariati berada dalam situasi tersebut, seperti tergambarkan pada sekilas biografinya. Sehubungan dengan itu wajar bila wacana yang dikembangkannya juga adalah wacana pemberontakan terhadap status quo, penindasan yang dialami diri dan masyarakatnya. Dikarenakan keterpengaruhannya dengan Gurvitch, landasan dialektika yang dianutnya bukan interes ekonomi (materialisme), tetapi nilai-nilai anutan, seperti yang telah dikemukakan sebelumnya. Jadi dia adalah seorang Hegelian. Tetapi dia menetapkan tempatnya yang khusus sebagai muslim, yaitu bahwa pondasi pemikirannya yang terdalam

${ }^{57 R a h m e n a, ~ “ A l i ~ S y a r i a t i . . . ”, ~} 216$. 
tersarikan dari al-Qur'an, sedangkan sosiologi hanya menjadi salah satu perangkat epistemologinya untuk mengartikulasikan nilai-nilai dasar yang diyakini dalam Islam.

Demikian sekilas upaya merekonstruksi pemikiran teologi sosial Syariati. Terlepas dari beberapa keterbatasan di dalamnya, saya berharap semoga hasil upaya ini menjadi bahan diskusi yang menarik. Wa al-Lâh a lam bi al-shawâh.

\section{Daftar Pustaka}

Ervand Abrahamian, Radical Islam: The Iranian Mujahedin (London: I. B. Tauris, 1989)

Shahrough Akhavi, "Shariati's Social Thought", dalam Religion and Politics in Iran, Shi'ism from Quietism to Revolution, ed. Nikkie R. Kiddie (New Haven and London: Yale University Press, 1983).

, "Ali Syariati", dalam The Oxford Encyclopedia of the Modern Islamic World, vol. IV, ed. John L. Esposito (New York: Oxford University Press, 1995).

Azumardi Azra, "Ali Syari'ati: Sejarah Masa Depan Umat Islam dan Akar-Akar Ideologi Revolusi Iran”, dalam Historiografi Islam Kontemporer: Wacana, Aktualitas, dan Aktor Sejarah (Jakarta: Gramedia Pustaka Utama, 2002), 208-238.

Mangol Bayat, "Islam Iran Masa Pahlevi dan Sesudahnya, Tinjauan Revolusi Kultural ?", dalam Islam dan Perubahan Sosial-Politik di Negara Berkembang, editor John L. Esposito, ter. Wardah Hafidz (Yogyakarta: PLP2M, 1985).

Charles Davis, (ed). Religion and the Making of Society: Essays in Social Theology, (New York \& Melbourne: Cambridge University Press, 1994)

Michael Fischer, Iran: From Religious Dispute to Revolution (Cambridge: Harvard University Press, 1980).

"Social Theology", http:/ / wmw.socialtheology.com, diakses tanggal 30 November 2009.

Gordon D Newby, A. Concise Encyclopedia of Islam (OxfordEngland: Oneworld Publications, 2004).

Ali Rahmena, An Islamic Utopian, A Political Biography of 'Ali Shari'ati (London and New York: I. B. Tauris, 1998). 
. "Ali Shariati: Teacher, Preacher, Rebel” dalam Pioneers of Islamic Revival, ed. Ali Rahnema (New York: Zed Books, 2005), 208-250; dalam versi bahasa Indonesia, "Ali Syariati: Guru, Penceramah dan Pemberontak", dalam Para Perintis Zaman Baru Islam, editor Ali Rahmena, ter. Ilyas Hasan (Bandung: Mizan, 1996).

Maulana Jalaluddin Rumi, Masnavi I Ma'navi_Teachings of Rumi The Spiritual Couplets, ter. E. H. Whinfield (Ames, Iowa: Omphaloskepsis, 2001).

Abulaziz Sachedina, "Ali Shariati: Ideologue of the Iranian Revolution”, dalam Voices of Resurgent Islam, ed. John L. Esposito (New York: Oxford University Press, 1983).

Ali Syariati, On the Sociology of Islam, ter. dan ed. Hamid Algar (Berkley: Mizan Press, 1979).

, School of Thought and Action, ter. Cyrus Bakhtiar (Albuquerque: Abjad).

Kritik Islam atas Marxisme dan Sesat-Pikir Barat

Lainnya, ter. Husin Anis Al-Habsy (Bandung: Mizan, 1983).

Tugas Cendekiawan Muslim, ter. Amin Rais (Jakarta: Rajawali Press, 1984).

, "Mesin dan Belenggu Mesinisme", dalam Peran

Cendekiawan Muslim Mencari Masa Depan Kemanusiaan, Sebuah Wawasan Sosiologis, ter. Team Naskah Salahuddin Press (Yogyakarta: Salahuddin Press, 1985).

, "Ideologi dan Kaum Intelektual", dalam Ideologi Kaum Intelektual, Suatu Wawasan Islam, ter. Farid Gaban, ed. Syafiq Basri dan dan Haidar Bagir (Bandung: Mizan, 1992). , Islam Madz̧bab Pemikiran dan Aksi, ter. M. S.

Nasrulloh dan Afif Muhammad (Bandung: Mizan, 1992). Membangun Masa Depan Islam, Pesan untuk para Intelektual Muslim, ter. Rahmani Astuti (Bandung: Mizan, 1993).

Pustaka Hidayah, 1993).

Islam Agama Protes, ter. Satrio Pinandito (Jakarta: , Agama versus "Agama", ter. Afif Muhammad dan Abdul Syukur (Jakarta: Pustaka Hidayah, 1994). 